Trifu, A.

\title{
HAPPINESS FACING TO THE PERFIDIOUS AND INVISIBLE CHALLENGE OF COVID-19
}

\author{
Alexandru Trifu \\ University „Petre Andrei” of lasi, Romania \\ trifu.alex@gmail.com
}

\begin{abstract}
In this study we are dealing with a new aspect of the problem in discussion that is the pursuing of Happiness, supported by institutions and regulations in the domain, but in moments of disturbances, in moments of crisis. We need to have goals, actions to be accomplished, in order to achieve the desired state of satisfaction or Happiness that anyone can have. We are in the presence of a double determination: the first one is represented by the material, especially money background, influencing the life and activities of households and entities and, the second one is represented by the reverse action that is of Happiness affecting the management and the activities of individuals, households and firms/organizations. The survey of the literature in the field, data from the World Health Organization, from the national authorities, analyses of the specialists in healthcare and economics, reports of the people in difficult health and economic situations are used in order to be able to synthesize the situation at this moment and possible forecasts regarding medical healing and economic recovery of the countries. Nothing is hard to manage, if you have knowledge, required abilities/skills to anticipate challenges or to make fast and right decisions, altogether at Micro and Macro-levels, in the benefit of all parts involved in. The huge interest is to reestablish the economies, mental health of people, i.e. the elements of a functional economic infrastructure.
\end{abstract}

Keywords: happiness, crisis, managers, perfidious virus, re-establishment.

\section{INTRODUCTION}

The literature in the field is quite abundant and relevant, but some outstanding sources need to be considered. For example, we want to highlight the ideas in this respect from Richard Easterlin, considered "the father of Economics of Happiness", to Andrew Oswald, J. E. Stiglitz, Amartya Sen, J.P. Fitoussi (we are interested in socio-economic approach of the problem).

The pursuing of Happiness is mandatory to be studied by the economists, in a straight collaboration with psychologists, because all aspects linked to the human personality and action matter, important being how to manage and preserve the most important factor of production and propeller of the tangible or not tangible goods and services flows in the world.

Thus, from the economic point of view, Easterlin (2004) focuses on the stress as important factor for life circumstances, particularly for people's income and employment situation. We are in the classic 
situation, in which money is the main cause to make people happier or more miserable, individual happiness appearing to be the same across poor and rich countries. Getting more money doesn't mean that the person is happier, a complex of goals and accomplishments, that ensure the life satisfaction and the desired state of Happiness, is needed to be taken into account. Interesting is the statistics of the answers to the most crucial question in this problem: are you or not a happy person? And the answer is "pretty happy", "happy", but almost never "too much happy".

Andrew Oswald's findings, both regarding USA economy and European economies, reveal that the state of happiness was rising, but in a small measure, therefore it seems that an extra income was not contributing to the quality of people's lives (Oswald, 1997). The business environment is capable, in normal conditions, to support and increase the people desires for life satisfactions, for thinking to scopes/goals which ensures the state of Happiness and, in reverse, this state to be capable to increase the efficiency of human activities and the well-functioning of households and firms.

The three eminent economists, J. E. Stiglitz, A. Sen, J.-P. Fitoussi (2009), tried to put in practice a new approach of what Statistics and its instruments is needed to do for a credible and outstanding image of social and economic indicators.

For our purpose, only the ideas regarding the subjective approaches of the life quality to be kept in mind are the following:

-it is not sufficient to look at people's choices and desires to make statements related to their well-being. It is needed to see people acting and managing in the different environments, to understand the human intrinsic value;

-the features obtained are based on the answers of people/workers to the questionnaires regarding their own activities, or how environmental processes or phenomena (such as inflation) affect the daily life and work.

For example, studies (Di Tella et al., 2001) reveal that people appear to be happier when inflation and unemployment, "the two Macroeconomic evils" are low.

This is no place to analyze different management phases or dimensions during crises (Boin, 2004) to set up plans of actions or operative capacities, the actual crisis is complex, impacting all activities and behaviors, from micro to macro entities and institutions.

\section{METHODOLOGY}

The analysis based on the survey of the literature in the field, data from the World Health Organization, from the national authorities, analyses of the specialists in healthcare and economics, reports of the people in difficult health and economic situations. From these sources, we will be able to synthesize the situation 
Trifu, A.

at this point and highlighting what are the challenges of the COVID-19 spread out and dangers already appeared or which will follow.

\section{HAPPINESS IS A SERIOUS JOB}

We paraphrase through this what is already done in this matter by the Government of United Arab Emirates (UAE), who set up a Ministry of Happiness in Dubai (Khaishgi, 2016). A lady Minister is in charge, Ohood Al Roumi, who affirmed that the achievements in UAE in all sectors of activity cannot be conceived without a state of confidence, trust and happiness. And, that's the role of the institution she runs, to bring happiness, an intrinsic condition for the development. The role of the Government, in the opinion of UAE rulers, is to create an appropriate environment where people can flourish, to reach their potential, in a sum, to become happy. For EAU, more precisely, this Ministry of Happiness has the task and responsibility to drive public policies towards getting social goods, satisfaction and, by consequence, we may say, prosperity.

This means that building and developing skills of people, self-confidence and power to overpass the difficulties (including that one of today) become, for the Government and public authorities a priority, along with providing goods and services in the economy.

Another significant example in this respect is present in Denmark, known under the name of Hygge (pronounced hoo-ga), largely translated as convenience, coziness. That is, a special, charming, relaxed and warm moment spent alone, or with friends.

For the Danes is a way of living and, also as in the previous case of EAU, we are dealing with an institution, the Happiness Research Institute in Copenhagen who exposed the hard core of the Danes Happy Living (Wiking, 2017).

But, precisely in our days, the meaning of Hygge, from a large point of view, must remain only in the sense of sitting round the table, discussing the big and small things in life, but only within the family, not including the friends and neighbors as the term analyzed implies.

At the same time, looking at The World Happiness situation and synthesized by Hurst on www.euronews.com, it turns out that Finland takes top for third year in a row, 2018, 2019, 2020 (Hurst, 2020). Thus, it is maintaining the so-called Nordic/Scandinavian group on the World's Happiness Report's top spots. We are saying this, based on the rankings, observing that since 2013 the five Nordic countries - Finland, Denmark, Norway, Sweden, and Iceland - have all been in the top ten of the annual list. 
Trifu, A.

HAPPINESS FACING TO THE PERFIDIOUS AND INVISIBLE CHALLENGE OF COVID-19

TABLE 1. TOP TEN HAPPY/LEAST HAPPY COUNTRIES OF THE WORLD

\begin{tabular}{|l|l|}
\hline \multicolumn{1}{|c|}{ Top ten happiest countries of the world } & \multicolumn{1}{c|}{ Ten least happy countries of the world } \\
\hline 1. Finland & 1. India \\
\hline 2. Denmark & 2. Malawi \\
\hline 3. Switzerland & 3. Yemen \\
\hline 4. Iceland & 4. Botswana \\
\hline 5. Norway & 5. Tanzania \\
\hline 6. The Netherlands & 6. Central African Republic \\
\hline 7. Sweden & 7. Rwanda \\
\hline 8. New Zealand & 8. Zimbabwe \\
\hline 9. Austria & 9. South Sudan \\
\hline 10. Luxembourg & 10. Afghanistan \\
\hline
\end{tabular}

Source: Hurst (2020), www.euronews.com

We want to insist on the variables, indicators, six in number, taken into account for the establishment of degree of happiness in each country:
a. GDP/capita;
b. Social support;
c. Healthy life expectancy;
d. Freedom;
e. Generosity;
f. Absence of corruption.

In the present context, people, workforce are primarily affected and from the above variables, firstly impacted are those ones dealing with personal and social issues, i.e. social support, healthy status, freedom. Immediately after, it comes the collapse of the economies and so on.

Outstanding is the fact that the environmental factors were taken into account to determine people's state of happiness, but unfortunately it was missing this tiny and dangerous enemy. We can affirm that, in the above-mentioned cases, we are dealing with the specific Nordic welfare state, which means regulations on social and work markets, the avoidance of exploitation and mitigate the inequalities effects in society.

Another strong point is represented by the efficient and transparent activities of the public institutions, with benefits both for themselves and for the people as contributors/taxpayers. Furthermore, this means the social cohesion is a strong indicator of Happiness within any country and supports the wellfunctioning of democracies and economies as a whole.

We arrived at the point in which is mandatory to see how Happiness affects not only the economic institutions, such as productivity (Sgroi, 2010), but how the internal human resources, the mental power and positive thinking are capable to influence our behavior in these new conditions and to determine, that's is the most important, the raise of human efficiency and re-gaining the well-functioning of all 
Trifu, A.

HAPPINESS FACING TO THE PERFIDIOUS AND INVISIBLE CHALLENGE OF COVID-19

economic and social activities, even though a reasonable and well-conducted management. Of course, we are talking about the opposite influencing sense: from Happiness and Trust (already accumulated) to productive activities.

We affirm that exactly the livelihoods, the money, at low levels, based on Easterlin theory, become the causes of the crises, source of anxiety, even panic. The situation should not be prolonged too much, something must be effectively done in slowing the spread of the virus, not only staying at home, working at home. This situation is needed to increase productive/service activities, not mainly, supporting the technical unemployment or other activities with government funds or from EU. As we see, all domains of the social-economic life are impacted directly or indirectly by the virus perfidious action. Therefore, the reserves have to be re-fillable in order to ensure a normal and efficient supportive flow.

But we face with losing the jobs, not only the extinct of technical unemployment. For example, Spain records more than 800,000 people losing their jobs (this figure is added to the already unemployment rate of $14 \%$ before the crisis stuck), as it is presented in McCaffrey briefing (April 2, 2020).

Probably, a relevant example to understand even how Happiness could affect the economic and social re-birth is that one of cosmonauts in a spaceship, dealing with solitude, dangers, anxiety and fear. But they must impose to give themselves tasks, goals, and then work on them, so that each day to be productive and full occupied (McCaffrey, April 2, 2020). Of course, the force is from inside the human body and mind, thinking in advance, to those things ensuring a decent/normal life existence and, after that, getting the state of satisfaction, even Happiness, and the circuit will go on.

The EU, for example, is focused to mitigate, as possible, from these very first stages of the pandemic, the economic and social effects of coronavirus lockdown throughout Europe. It's about a new fund, of 100 billion euro, with destination supporting those people left out of work, 1 million people until present (Psara, 2020). This fund, precisely payment scheme, is called SURE (Support to mitigate Unemployment Risks in an Emergency) and it's a loan to those Member-States that need the money for strengthening the short-time work schemes. That is, we talk about short-term programs to mitigate the economic collapse, in fact as possible trough moment (i.e. the point where the economy hits the lower level of recession) and to prepare the recovery of the activities, exactly as in business/economic cycles. Furthermore, the World Health Organization in its Report of April 62020 affirmed that almost 90\% of the world students are affected by nationwide school closures, that is more than 1.5 billion children and young people. And, another aspect to be held by the people, is the opinion expressed in a joint press conference of the WHO Director General and IMF Managing Director regarding the importance of saving lives and saving livelihoods and it's a false dilemma (our emphasize) the existence of a trade-off between saving lives and saving jobs. 
Returning to Andrew Oswald (1997), in accordance with the purpose of our study, we may underline that economic things matter only in so far as they make people happier. But, the idea and the reality, at the same time, demonstrate that the longer a country's economy essential components remains shut down, the higher the number of insolvencies and closures of entities, especially SMEs. It will follow a higher rate of unemployment, possible inflation, higher costs which will be paid by all of us in the years to come.

If, in these moments, we could think of the mean of Hygge House (enlarging the sphere, the workplace) $\rightarrow$ trying to make an ordinary day, using simple moments or activities, being active and in a slower lifestyle, it would be wonderful and hopeful in this busy and unpredictable world.

\section{CONCLUSIONS}

We are facing now with perfidious and invisible danger/challenge from the environment, COVID-19, that destroys the structures of common life and of the economies. Everything is affected and it is needed a prompt and concerted response to this destabilizing factor.

Therefore, in this particular situation it is difficult to say which management models are more appropriate. As we already saw, it is a straight inter-connection between macro policies-political and institutional- and the micro management decision-making, with the State supporting the mitigation of the abrupt curve of recession and, altogether with the entities, following to reach in a shorter period of time, to the trough point of the cycle.

We think it matters that, during this crisis, the political decision-makers, the managers, leaders operate in full public view and it's mandatory to do so, because people has to know and to understand mostly the measures taken, one of them tough, cruel, but necessary.

Speaking about countries with high level of the Happiness indicators, maybe in their cases we can affirm that it exists a "stock of happiness in the society", a very important psychological resource, ensuring a common effort of households, firms, organizations towards maintaining a proper status of mind, a positive thinking and trust in overwhelming difficulties occurred, or which may occur as a result of the social and economic situations of today.

Nothing is hard to manage, if you have knowledge, required abilities/skills to anticipate challenges or to make fast and right decisions, altogether Micro and Macro-levels, in the benefit of all parts involved in. The huge interest is to re-establish the economies, mental health of people, i.e. the elements of a functional economic infrastructure.

In this time of crisis, Happiness can mean to feel safe, in solidarity with other people. The employers and managers have to understand that the well-being enhances the activity and, therefore, taking into 
Trifu, A.

HAPPINESS FACING TO THE PERFIDIOUS AND INVISIBLE CHALLENGE OF COVID-19

account the decisions made by the national or international institutions/organizations, to proceed to adequate tactics, small steps, towards stopping the collapse of the businesses and reviving them. Indefinite periods of lockdown are simply unsustainable for the economies of today.

Following this idea, some countries, among them Finland, Belgium, France prepare plans for a gradual easing of stay-at-home orders. Much more, Austria is the first EU country which announces a possible re-opening of small shops and shopping centers, i.e. exactly the businesses are back.

\section{REFERENCES}

Boin, A. (2004). Lessons from Crisis Management. International Studies Review. 6(1): 165-194.

Di Tella, R., MacCulloch, R. J., \& Oswald, A. J. (2001). Preferences over inflation and unemployment: Evidence from surveys of happiness. American economic review, 91(1), 335-341.

Easterlin, R. (2004). The Economics of Happiness. Daedalus, 133(2): 26-33.

Hurst, L. (2020). World Happiness: Finland takes top ranking for third year in a row. Retrieved March $25^{\text {th }}, 2020$, from https://www.euronews.com/2020/03/20/world-happiness-finland-takes-top-rankingfor-third-year-in-a-row.

Khaishgi, A.E. (2016). Happiness is a serious job: UAE'S Ministry of Happiness embraces new role. Retrieved March 2 ${ }^{\text {nd }}$, 2020, from https://www.thenational.ae/uae/government/happiness-is-a-seriousjob-uae-s-minister-of-happiness-embraces-new-role-1.201750.

McCaffrey, D. (2020). Coronavirus Briefing. Retrieved April $3^{\text {rd }}$, 2020, from www.euronews.com-April

Oswald, A. J. (1997). Happiness and economic performance. The economic journal, 107(445), 18151831.

Psara, M., Gill, J. (2020). EU hopes to mitigate lockdown and help workers with 100-billion-euro fund.

Retrieved April $3^{\text {rd }}$, 2020, from https://www.euronews.com/2020/04/02/eu-hopes-to-mitigatelockdown-and-help-workers-with-100-billion-fund.

Sgroi, D. (2010). Happiness economics in reverse: Does happiness affect productivity? Retrieved March 15 ${ }^{\text {th }}, 2020$, from https://voxeu.org/article/does-happiness-affect-productivity.

Stiglitz, J. E, Sen, A., Fitoussi, J-P. (2009). Report by the Commission on the Measurement of Economic Performance and Social Progress, publisher Commission on the Measurement of Economic Performance and Social Progress, Paris. Retrieved March 25 th, 2020, from www.ec.europa.eu/eurostat/

Wiking, M. (2017). The Little Book of Hygge: Danish Secrets to Happy Living. The Happiness Institute Series, Hardcover, January

World Health Organization Coronavirus disease 2019 (COVID-2019), Situation report, 6 April, 2020. Retrieved April $7^{\text {th }}, 2020$ from www.who.int/docs 